\title{
A new, improved sensor for ascorbate determination at copper hexacyanoferrate modified carbon film electrodes
}

Received: 29 June 2004/ Revised: 27 October 2004/ Accepted: 5 November 2004/Published online: 10 February 2005

(C) Springer-Verlag 2005

\begin{abstract}
A new, improved sensor for the electrocatalytic determination of ascorbate has been developed that has both a low applied operating potential and a low detection limit. The sensor was constructed by depositing copper hexacyanoferrate film either electrochemically or chemically onto carbon film electrode, and it was then characterised by cyclic voltammetry and electrochemical impedance spectroscopy. Chemically deposited films were shown to be the best for ascorbate determination and were used as an amperometric sensor at $+0.05 \mathrm{~V}$ versus SCE to determine ascorbate in wines and juice. The linear range extended to $5 \mathrm{mM}$ with a limit of detection of $2.1 \mu \mathrm{M}$, the sensor was stable for more than four months, and it could be used continuously for at least 20 days.
\end{abstract}

Keywords Ascorbate Amperometric sensor · Carbon film electrodes ' Copper hexacyanoferrate Vitamin $\mathrm{C}$ in foods

\section{Introduction}

Ascorbic acid (AA) is one of most important biological compounds for human metabolism. Moreover, it is used to treat some illnesses such as the common cold, cancer and AIDS [1]. Although AA is an readily oxidisable compound, even in air [2], some compounds - particularly hexacyanoferrates - catalyse the oxidation of AA [3]. Hexacyanoferrate(III) reacts with AA chemically in acidic medium [3] (see Scheme 1). This reaction is used to determine AA spectrophotometrically in pharmaceutical products [4-6].

R. Pauliukaite $\cdot$ M. E. Ghica · C. M. A. Brett $(\bowtie)$

Departamento de Quimica, Universidade de Coimbra,

3004-535 Coimbra, Portugal

E-mail: brett@ci.uc.pt

Tel.: + 351-239-835295

Fax: + 351-239-835295
Prussian Blue films have also been found to have an electrocatalytic effect on the oxidation of AA [7-9] and they have also been used for its determination [10]. An amperometric flow-injection sensor for AA was developed using a Prussian Blue film on a glassy carbon electrode; such a sensor was stable, sensitive and selective and had a low detection limit $(2.5 \mu \mathrm{M})$ in acidic media [11]. Analogues of Prussian Blue have also been applied in electrochemical studies of the oxidation of AA, particularly nickel [12,13], copper [14], and cobalt hexacyanoferrates [15].

Other amperometric AA sensors include electrodes chemically modified with 7,7,8,8-tetracyanoquinodimethane [16], osmium 2,2'-bipyridyl poly-4-vinylpyridine chloride complex [17], lanthanum 2,6-dichlorophenolindophenol [18], electropolymerized $N, N$-dimethylaniline [19], manganese dioxide [20] and a cobalt (II) phthalocyanine doped with iodine for potentiometric determination [21]; a hanging mercury drop electrode [22] was also used to oxidise AA. The electrocatalytic oxidation of AA on conducting polymer electrodes, in particular on polyaniline, has also been studied [23].

AA has often been reported to be an interfering compound in biosensors based on Prussian Blue [24] or titania sol-gel [25] in the determination of glucose [2327] or hydrogen peroxide [26]. In order to avoid this AA interference in glucose measurements, the operating potential of the sensor was decreased to $0.0 \mathrm{~V}[24,26]$. A Nafion layer was applied to the surface of the biosensor [25] or the enzyme was immobilized in a polymer, such as $o$-aminophenol [27], and placed on top of the Prussian Blue layer. Nevertheless, in [28] minor interference from AA was observed even at $+0.2 \mathrm{~V}$.

Copper hexacyanoferrate $(\mathrm{CuHCF})$ is one of the Prussian Blue analogues most commonly used to determine alkali cations [13, 29], particularly potassium and sodium [30]. Some amperometric sensors based on $\mathrm{CuHCF}$ have been developed for the determination of hydrogen peroxide [31], sulphur dioxide [32], sulfhydryl [33] and traces of ammonia [34]. CuHCF has also been 

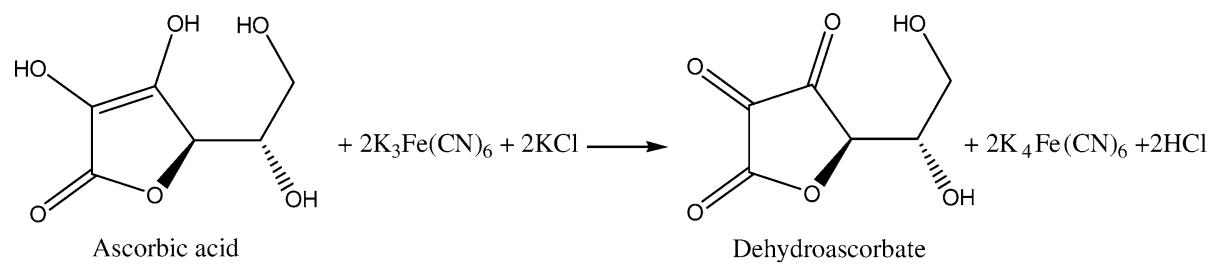

Scheme 1

used as a mediator in the development of biosensors [13, 35], particularly glucose [36-38].

The aim of this work was to develop a new and improved sensor for ascorbate determination that works at a lower potential than other sensors. Since Prussian Blue films are not sufficiently stable in neutral media, they are not suitable for ascorbate determination at $\mathrm{pH}$ 7. It was demonstrated in [14] that $\mathrm{AA}$ is easily oxidized at cupric hexacyanoferrate, so this Prussian Blue analogue film was deposited in various ways, characterised electrochemically, and successfully used for ascorbate determination.

\section{Experimental}

Chemicals and solutions

$\mathrm{CuCl}_{2} \cdot 2 \mathrm{H}_{2} \mathrm{O}$ and $\mathrm{K}_{3} \mathrm{Fe}(\mathrm{CN})_{6}$ were purchased from Merck (Germany), AA was obtained from Sigma (Germany). Enzymatic test kits for the determination of L-ascorbic acid in foodstuffs by a colorimetric method were obtained from Boehringer Mannheim/R-Biopharm (Germany).

$0.1 \mathrm{M}$ phosphate buffer saline solution (PBS), $\mathrm{pH}$ 7.0, was prepared from sodium dihydrogenphosphate, disodium hydrogenphosphate (Riedel-de-Haën), and $0.05 \mathrm{M} \mathrm{NaCl}$. A $0.1 \mathrm{M}$ stock solution of AA was prepared every week and kept at $4{ }^{\circ} \mathrm{C}$. Millipore Milli-Q nanopure water (resistivity $>18 \mathrm{M} \Omega \mathrm{cm}$ ) was used to prepare all solutions. Experiments were performed at room temperature $\left(25 \pm 1^{\circ} \mathrm{C}\right)$.

The samples used for ascorbate analysis were obtained in Portugal: white and red Portuguese wine; ice tea with lemon, and $100 \%$ orange juice produced in Portugal. "Cebion", a pharmaceutical portioned vitamin $\mathrm{C}$ powder (1.00 g vitamin $\mathrm{C}$ per portion), produced by Merck, was also analysed.

\section{Electrode preparation}

The electrodes were made from carbon film resistors ( $\sim 2 \Omega$ resistance) $[39,40]$. The resistors were fabricated from ceramic cylinders of external diameter $1.5 \mathrm{~mm}$ and length $4.0 \mathrm{~mm}$ by pyrolytic deposition of carbon. One of the tight fitting metal caps, joined to a thin conducting wire, was removed from one end of the resistor and the other wire was sheathed in plastic tube, covering the metal cap with epoxy resin. In this way, the exposed geometric area of the electrode was $\sim 0.2 \mathrm{~cm}^{2}$. Before use, the electrodes were electrochemically pre-treated by cycling between 0 and $1 \mathrm{~V}$ versus a saturated calomel electrode (SCE) in $0.05 \mathrm{M} \mathrm{KCl}$ solution for five to ten cycles until stable cyclic voltammograms (CVs) were obtained. Copper hexacyanoferrate was deposited from a solution containing $10 \mathrm{mM} \mathrm{Cu}^{2+}, 10 \mathrm{mM} \mathrm{K}_{3} \mathrm{Fe}(\mathrm{CN})_{6}$, and $100 \mathrm{mM} \mathrm{KCl}$ by one of three methods: chemically, by immersing the electrodes for $50 \mathrm{~min}$ in the solution of the precursor salts; galvanostatically, by applying a current of $-100 \mathrm{~mA} \mathrm{~cm}{ }^{-2}$ for $300 \mathrm{~s}$; by cycling the potential 25 times between +0.25 and $+0.90 \mathrm{~V}$ at a scan rate of $50 \mathrm{mV} \mathrm{s}^{-1}$. The electrodes were then dried with a stream of hot air, and left at room temperature for $48 \mathrm{~h}$ to stabilise.

\section{Methods and instruments}

The three-electrode electrochemical cell contained a $\mathrm{CuHCF}$-coated carbon film working electrode, a platinum foil counter electrode, and a saturated calomel electrode (SCE) as reference. Measurements were performed using a computer-controlled $\mu$-Autolab Type II

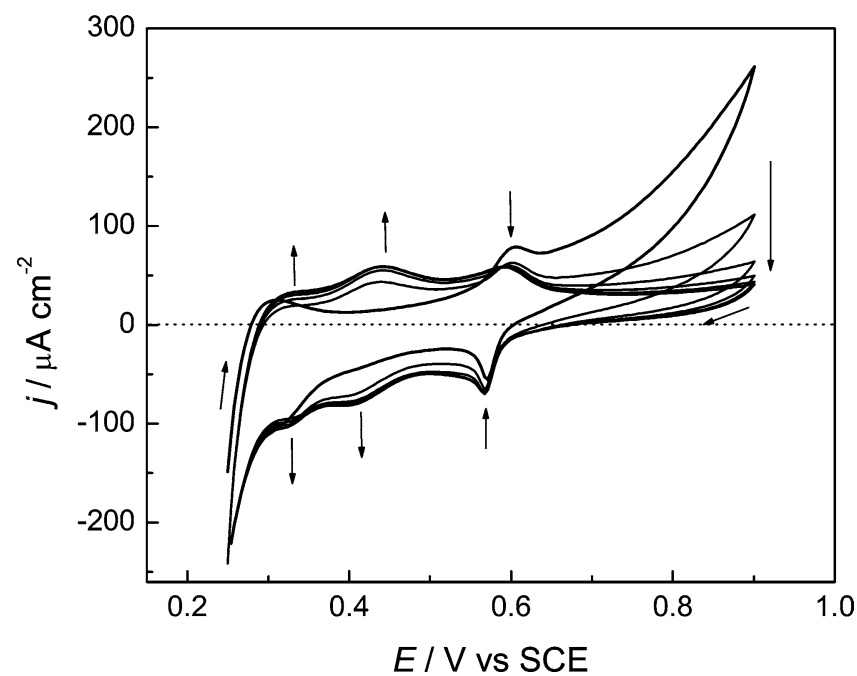

Fig. 1 Deposition of CuHCF, using potential cycling on carbon film resistor electrodes, from a solution containing $10 \mathrm{mM} \mathrm{CuCl}$, $10 \mathrm{mM} \mathrm{K}_{3}\left[\mathrm{Fe}(\mathrm{CN})_{6}\right]$ and $0.1 \mathrm{M} \mathrm{KCl}$, at $\mathrm{pH} 2.76$ (adjusted with $\mathrm{HCl})$ 
potentiostat/galvanostat with GPES 4.9 software (Eco Chemie, Netherlands).

Electrochemical impedance measurements were carried out in the same electrochemical cell with a PCcontrolled Solartron 1250 frequency response analyser coupled to a Solartron 1286 electrochemical interface using ZPlot 2.4 software (Solartron Analytical, UK). A sinusoidal voltage perturbation of amplitude $10 \mathrm{mV}$ was applied, scanning from $65 \mathrm{kHz}$ to $0.1 \mathrm{~Hz}$ with 10 points per frequency decade, integration time $120 \mathrm{~s}$. Fitting to equivalent circuits was performed with ZView 2.4 software.

\section{Results and discussion}

Deposition and electrochemical characterisation of $\mathrm{CuHCF}$ films

The CuHCF films were deposited in three different ways: chemically, galvanostatically, and by potential cycling, which is the most common method used to obtain $\mathrm{Cu}$ HCF films [31, 34, 38]. The concentration of the precursor salts was always the same (the deposition conditions are described in the Experimental section). Films were dried with hot air and aged for $48 \mathrm{~h}$ (details in the Experimental section). The changes in electrochemical characteristics of the films observed during cyclic voltammetry $(\mathrm{CV})$ are presented in Fig. 1. The potential cycling deposition was rapid up to ten cycles, until a homogeneous film was obtained; the deposition rate then dropped and the CVs remained almost unchanged with further cycling. Similar behaviour was obtained during galvanostatic deposition of the film - the potential changed rapidly up to $5 \mathrm{~s}$, and then remained almost constant at around $0.22 \mathrm{~V}$ versus SCE.

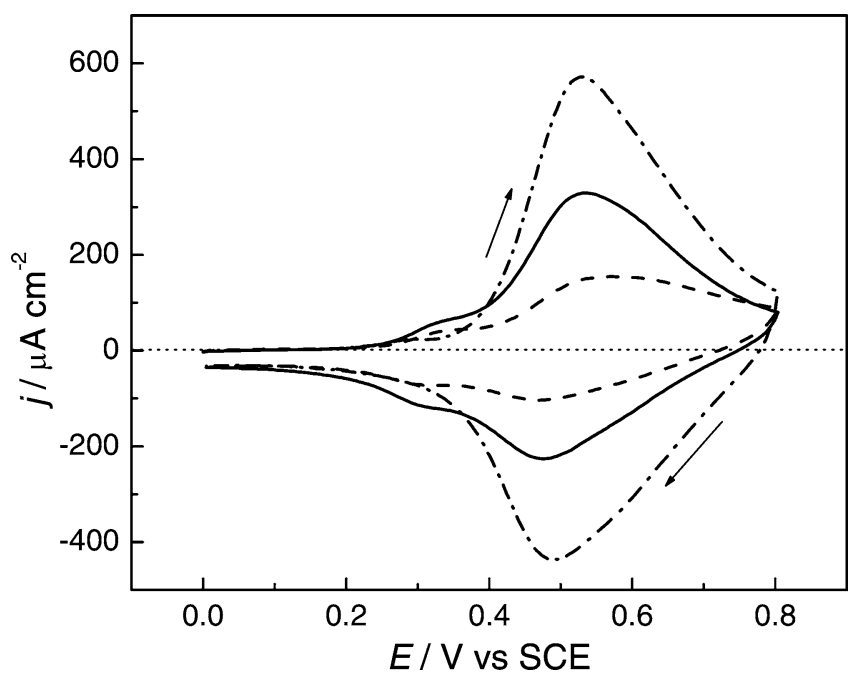

Fig. 2 Cyclic voltammograms of CuHCF films in phosphate buffer saline, $\mathrm{pH}$ 7.0, deposited: (solid line) via potential cycling, (broken line) galvanostatically, and (broken line with dots) chemically. Scan rate $50 \mathrm{mV} \mathrm{s}^{-1}$
Figure 2 shows the electrochemical behaviours of all three $\mathrm{CuHCF}$ films in 0.1 M PBS, pH 7.0. The observed currents were different at the various films due to the different thicknesses and structures as happens with Prussian Blue films [8]. The thickest film, as expected, was obtained by chemical deposition [41], and the thinnest by galvanostatic deposition. The different structure of the films can be seen from the shapes of the CVs and the peak positions, which differed slightly for the CuHCF films deposited in the three ways. Electrochemically deposited films have two redox couples: $\mathrm{Cu}^{+} \leftrightarrow \mathrm{Cu}^{2+}$ and $\left[\mathrm{Fe}^{\mathrm{II}}(\mathrm{CN})_{6}\right]^{4-} \leftrightarrow\left[\mathrm{Fe}^{\mathrm{III}}(\mathrm{CN})_{6}\right]^{3-}[14] ;$ at the chemically deposited film the first redox couple was suppressed so that only the second one was clearly exhibited.

Electrochemical impedance spectra recorded at $+0.05 \mathrm{~V}$ versus $\mathrm{SCE}$ at the various films show some differences between the different deposition methods; see Fig.3. Both electrochemically deposited films had very similar impedance values (lower in the case of galvanostatic deposition), while those from chemically deposited
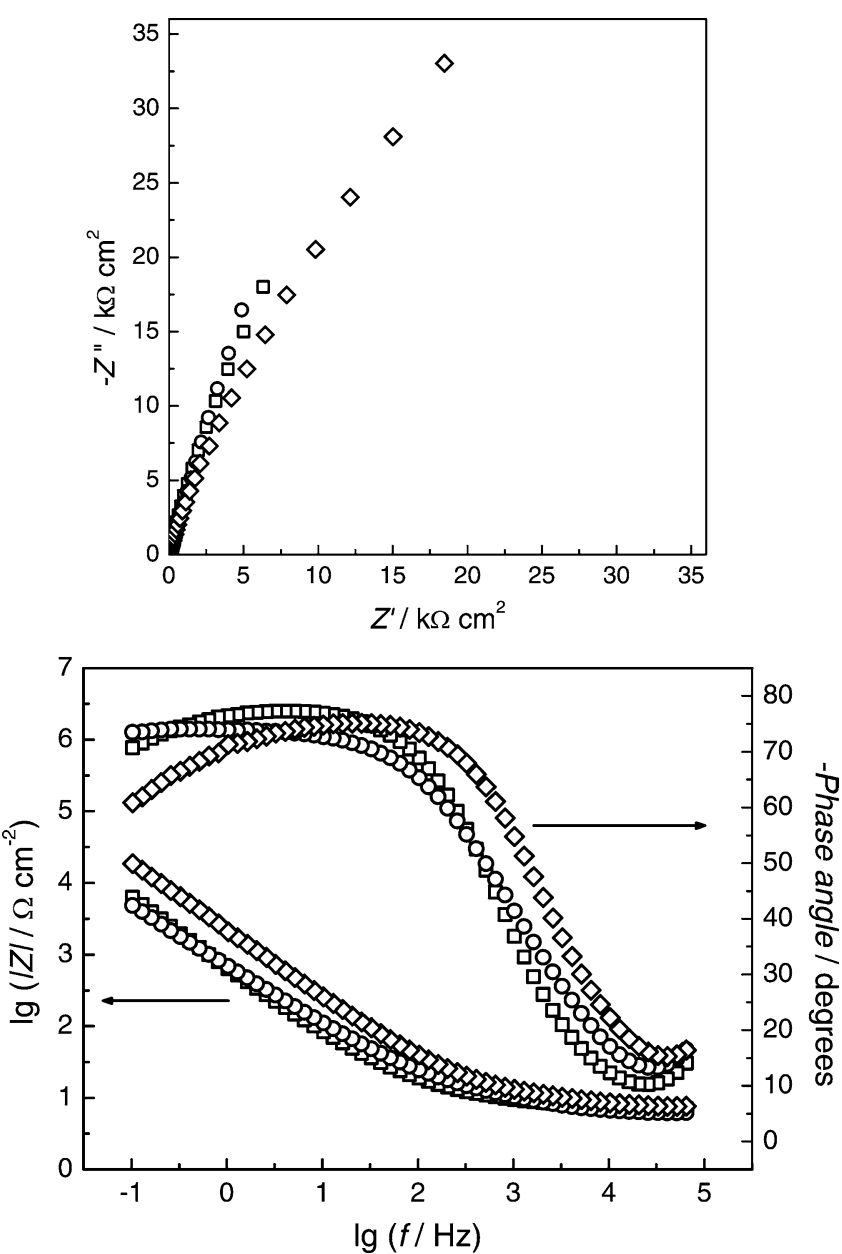

Fig. 3 Complex plane impedance spectra and Bode plots for $\mathrm{CuHCF}$ films prepared: (open squares) via potential cycling, (open circles) galvanostatically, and (open diamonds) chemically. Spectra recorded in $0.1 \mathrm{M} \mathrm{KCl}$ solution at $+0.05 \mathrm{~V}$ versus SCE 
CuHCF films were higher, suggesting fewer defects in the structure. Thus, the trends in the data obtained are in agreement with the cyclic voltammetry results at these films. Modelling was performed using a simple resistance and constant phase element ( $R$-CPE) parallel combination equivalent circuit in series with the cell resistance, as done at the carbon film substrate electrodes [40]. The constant phase element, CPE, represents the roughness of the surface and consequent frequency dispersion and, as found at the carbon film, the values of the exponent were around 0.85 . The fitted values of capacity were $74.5,89.3$, and $23.3 \mu \mathrm{F} \mathrm{cm} \mathrm{cm}^{-2}$ for CuHCF films deposited by potential cycling, galvanostatically, and chemically, respectively and the values of $R$ were between 100 and $200 \mathrm{k} \Omega \mathrm{cm}^{2}$, slightly higher than at the carbon film substrate. The last of these is substantially different to the others. Impedance spectra of the $\mathrm{CuHCF}$ are different to those obtained at some other hexacyanoferrates [42, 43]. However, in [42] galvanostatic deposition of PB has been carried out at indium tin oxide substrate, and in [43] a Ni hexacyanoferrate bulk composite electrode was prepared. Our different results may be partly due to the fact that the carbon film substrate is not completely covered.

\section{Electrocatalytic oxidation of ascorbate at $\mathrm{CuHCF}$}

CuHCF deposited chemically was used to study the electrocatalytic oxidation of ascorbate, because this film was the thickest and exhibited the best electrochemical properties. The redox peaks of $\mathrm{CuHCF}$ decreased with each addition of AA to the buffer solution (Fig. 4), and an additional wave appeared for ascorbate oxidation at $+0.40 \mathrm{~V}$, which was shifted to more positive potentials with the addition of a new aliquot of AA, although the corresponding current did

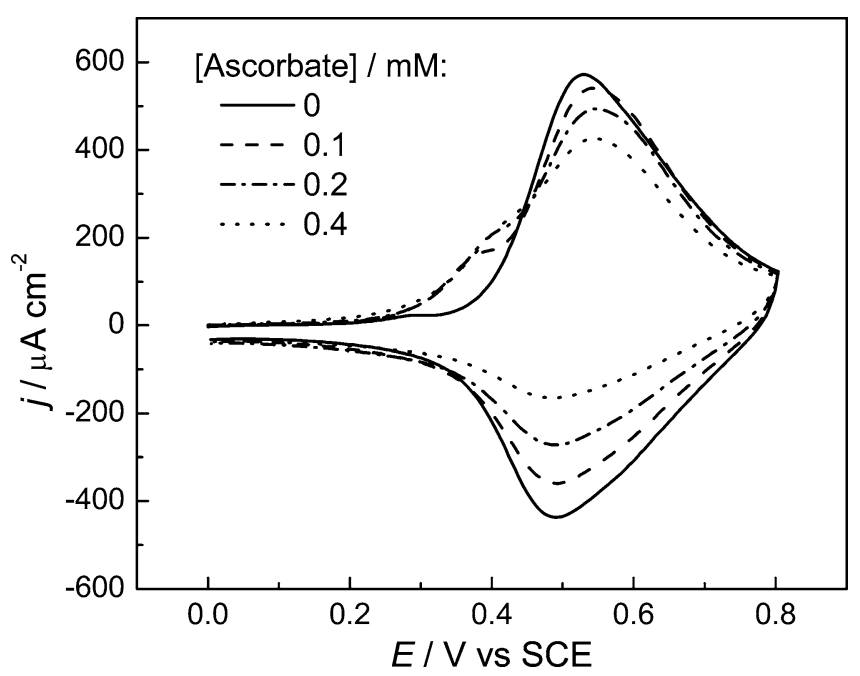

Fig. 4 Cyclic voltammograms showing the oxidation of ascorbate in $0.1 \mathrm{M}$ phosphate buffer saline, $\mathrm{pH} 7.0$, at chemically deposited CuHCF film. Scan rate $50 \mathrm{mV} \mathrm{s}^{-1}$ not increase proportionally with the added concentration of AA. Fast oxidation probably only occurs when a monolayer of the ascorbate is adsorbed, and at high concentrations adsorption is the limiting step of the electrochemical process. This fact led us to conclude that cyclic voltammetry is not a suitable method for ascorbate determination, and that fixed-potential amperometry is preferable.

Shankaran and Narayanan [14] mechanically immobilised $\mathrm{CuHCF}$ on the surface of a graphite electrode and performed electrocatalytic oxidation of $\mathrm{AA}$ in $0.1 \mathrm{M} \mathrm{NH}_{4} \mathrm{Cl}$ using cyclic voltammetry. The oxidation peak of AA appeared at the same position that $\mathrm{Cu}^{+} /$ $\mathrm{Cu}^{2+}$ took place: the oxidation peak increased proportionally with the amount of AA in the solution. It is probable that we obtained a different $\mathrm{CuHCF}$ structure from that in [14], since in that case a different ratio of precursor salts and deposition method was used. A similar electrocatalytic effect was observed at cobalt hexacyanoferrate films deposited in two steps: by potentiostatically depositing Co and then immersing it into acidic potassium hexacyanoferrate(III) solution. However, that electrode was not applied to the analytical determination of AA [15].

Optimisation of the sensor for ascorbate determination

The sensor based on CuHCF film was applied to the determination of ascorbate in amperometric mode. The response to ascorbate at 0.00 and $+0.025 \mathrm{~V}$ was poor, but at $+0.05 \mathrm{~V}$ the response was sufficiently good to determine ascorbate in the micromolar range. At higher potentials the sensitivity increased further, but was never better than other existing sensors [14, 17-21]. Therefore, the operating potential was chosen to be $+0.05 \mathrm{~V}$. All three types of $\mathrm{CuHCF}$ films (deposited by cycling of the potential, galvanostatically and chemically) were calibrated for the ascorbate anion. Calibration data are presented in Fig. 5 and data from the calibration curves are given in Table 1. As expected, the thinnest film - that obtained by galvanostatic deposition - gave the best response. However, although the film obtained by CV deposition was thinner than the chemical one, the response was poorer. This is probably related to the different structures of the films obtained by alternative deposition methodologies.

As seen from Fig. 5, films obtained by $\mathrm{CV}$ and chemical deposition exhibit two linear ranges. The first is up to 0.01 or $0.30 \mathrm{mM}$ at voltammetrically and chemically deposited films, and the second is up to $5 \mathrm{mM}$ (data in Table 1 are calculated from the upper range). The first linear range is probably related to the adsorption of a monolayer of ascorbate at the surface of the electrode; due to the different structures of the films, the adsorption mechanism at voltammetrically and chemically deposited films should be different from that at $\mathrm{CuHCF}$ obtained by galvanostatic deposition. 
Table 1 Sensitivities, intercepts, limits of detection and limits of quantification calculated from ascorbate calibration curves (see Fig. 5) obtained at $\mathrm{CuHCF}$ films deposited in various ways

\begin{tabular}{|c|c|c|c|c|c|c|}
\hline $\begin{array}{l}\text { CuHCF film } \\
\text { preparation method }\end{array}$ & $\begin{array}{l}\text { Sensitivity } \\
(\mu \mathrm{A} \mathrm{mM})^{-1}\end{array}$ & $\begin{array}{l}\text { Intercept } \\
(\mu \mathrm{A})\end{array}$ & $\begin{array}{l}\text { LOD } \\
(3 \sigma, \mu \mathrm{M})\end{array}$ & $\begin{array}{l}\text { LOQ } \\
(10 \sigma, \mu \mathrm{M})\end{array}$ & $\begin{array}{l}\text { Correlation } \\
\text { coefficient }\left(R^{2}\right)\end{array}$ & $\begin{array}{l}\text { Linear range } \\
(\mathrm{mM})\end{array}$ \\
\hline Potential cycling & $0.80 \pm 0.02$ & $0.30 \pm 0.10$ & 3.65 & 121.7 & 0.995 & $0.15-5.00^{\mathrm{a}}$ \\
\hline Chemical & $1.40 \pm 0.03$ & $0.41 \pm 0.14$ & 2.10 & 170.1 & 0.997 & $0.20-5.00^{\mathrm{a}}$ \\
\hline
\end{tabular}

${ }^{\text {a } U p p e r ~ l i n e a r ~ r a n g e ~}$

Besides sensitivity and selectivity, stability is also a very important factor for the sensor. It is well known that Prussian Blue is unstable in neutral media [13, 29], but the CuHCF film sensor is reported to be stable in slightly acidic medium $\left(0.1 \mathrm{M} \mathrm{NH}_{4} \mathrm{Cl}\right.$ solution) [14]. Its stability also depends on the deposition and operating conditions [13,31-35]. Our investigation showed that $\mathrm{CuHCF}$ is definitely more stable than Prussian Blue, but its operating stability depends on the deposition conditions (Fig. 6). The critical period was the first week, when the response to ascorbate at the electrochemically deposited $\mathrm{CuHCF}$ changed quite
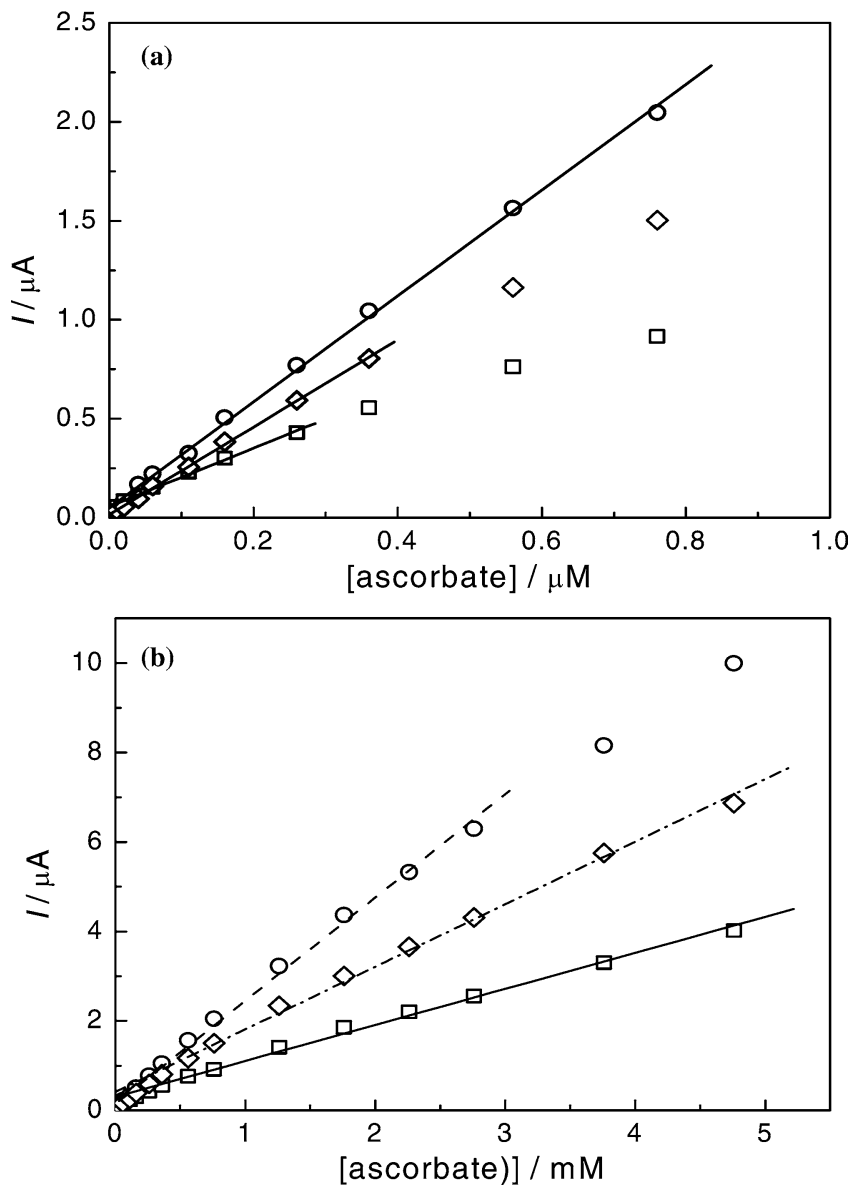

Fig. 5 Calibration curves of ascorbate at $\mathrm{CuHCF}$ films deposited: (open squares) via potential cycling, (open circles) galvanostatically, and (open diamonds) chemically. Operating potential $+0.05 \mathrm{~V}$; supporting electrolyte $0.1 \mathrm{M}$ phosphate buffer saline, $\mathrm{pH}$ 7.0. a Lower concentration range; $\mathbf{b}$ higher concentration range a lot; it either decreased (at CV film by $48 \%$ ) or increased (at galvanostatic film by $55 \%$ ). The films probably became thinner out until a particular thickness was reached at neutral $\mathrm{pH}$, and after one week the response stabilised and remained stable (with a small decrease in response) for up to 20 days, when it became approximately $50 \%$ of the initial value. The chemically deposited film was stable for up to ten days and then the response slowly decreased. Since the film was thick, a small loss of thickness during the measurements was not significant enough to cause changes in the adsorption mechanism of ascorbate and the sensor response.

These facts also demonstrate that chemically deposited $\mathrm{CuHCF}$ film is the most suitable for sensing ascorbate, so all further measurements were performed at these electrodes. The relative standard deviation at this electrode was $3.5 \%(n=5)$ and the reproducibility of the sensors was $\sim 7.7 \%$ (calculated from the response at four electrodes).

The storability of this new $\mathrm{CuHCF}$ film sensor is at least several months in air at room temperature, representing a significant improvement on previously reported ascorbate or AA electrochemical sensors, which either work at a more positive potential than $+0.05 \mathrm{~V}$ versus SCE [11, 14, 18, 19, 44-46] or have higher

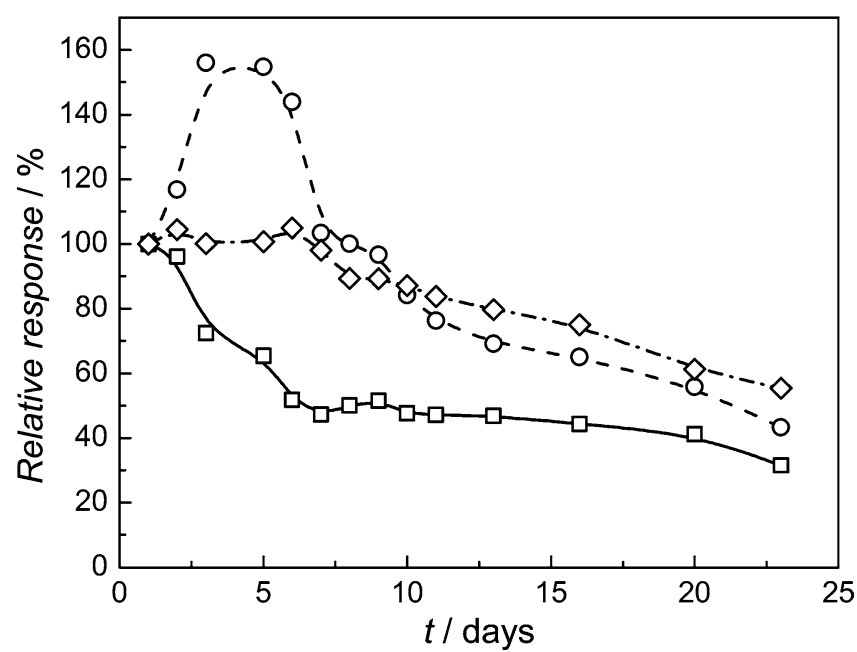

Fig. 6 Response to $0.55 \mathrm{mM}$ ascorbate over time in $0.1 \mathrm{M}$ phosphate buffer solution at $\mathrm{CuHCF}$ films deposited: (open squares) via potential cycling, (open circles) galvanostatically, and (open diamonds) chemically. Experimental conditions as in Fig. 5 
Table 2 Interference of some compounds on the response to ascorbate at $\mathrm{CuHCF}$ film deposited chemically

\begin{tabular}{lll}
\hline Compound & $\begin{array}{l}\text { Ascorbate:interfering } \\
\text { compound }\end{array}$ & $\begin{array}{l}\text { Relative } \\
\text { response/percent }\end{array}$ \\
\hline Fructose & $1: 5$ & 100 \\
Glucose & $1: 5$ & 100 \\
Acetic acid & $1: 5$ & 100 \\
Citric acid & $1: 1$ & 98 \\
& $1: 5$ & 91 \\
Tartaric acid & $1: 5$ & 100 \\
Catechol & $1: 1$ & 101 \\
& $1: 5$ & 109 \\
Phenol & $1: 5$ & 94 \\
$\mathrm{SO}_{4}^{2-}$ & $1: 5$ & 97 \\
\hline
\end{tabular}

All of the experimental conditions are the same as in Fig. 5

detection limits $[18,19,44]$. The sensor most similar to that presented here works at $+0.05 \mathrm{~V}$ versus $\mathrm{Ag} / \mathrm{AgCl}$ and has a detection limit of $23 \mu \mathrm{M}$ for $\mathrm{AA}$, and was developed by Kulys et al [16] based on tetracyanoquinodimethane-modified printed graphite electrodes.

A study of interferences from compounds usually present in food was also performed, and the results are shown in Table 2. The main sugars and acids usually present in wine and juice did not interfere, except citric acid to a small extent, which decreased the response to ascorbate by $10 \%$ at a five-fold excess. Some phenolic compounds present in the wine - such as phenol and catechol as well as sulphate ions-led to a small interference: catechol increased the AA response signal, but phenol and sulphate anion had the opposite effect. However, such interferences should not play a significant role in the determination of ascorbate by standard addition in wine and juice; moreover, the interfering compounds are present at small concentrations.

\section{Ascorbate determination in market samples}

Ascorbate was measured in some wine samples, orange juice, and ice tea with lemon.

Table 3 Amount of ascorbate found in wines, ice tea and juice at a $\mathrm{CuHCF}$-based ascorbate sensor

\begin{tabular}{lll}
\hline Sample & \multicolumn{2}{l}{ Ascorbate concentration } \\
\cline { 2 - 3 } & CuHCF sensor & Reference method \\
\hline Red wine & $150 \pm 4 \mu \mathrm{mol} \mathrm{L}{ }^{-1}$ & $155 \pm 2 \mu \mathrm{mol} \mathrm{L}^{-1}$ \\
White wine & $1.00 \pm 0.01 \mu \mathrm{mol} \mathrm{L}^{-1}$ & - \\
Red wine & $144 \pm 9 \mu \mathrm{mol} \mathrm{L}^{-1}$ & $155 \pm 2 \mu \mathrm{mol} \mathrm{L}^{-1}$ \\
Red wine & $2.1 \pm 0.1 \mu \mathrm{mol} \mathrm{L}$ & - \\
Ice tea with lemon & $28.0 \pm 0.1 \mu \mathrm{mol} \mathrm{L}$ & $28.3 \pm 0.3 \mu \mathrm{mol} \mathrm{L}^{-1}$ \\
Orange juice & $1.5 \pm 0.2 \mathrm{mmol} \mathrm{L}^{-1}$ & $1.1 \pm 0.2 \mathrm{mmol} \mathrm{L}^{-1}$ \\
\hline
\end{tabular}

Experimental conditions as in Fig. 5

a Mean value of the concentrations calculated from three measurements

$\mathrm{b}$ Colorimetric method with enzymatic test kit; detection limit $3 \mu \mathrm{mol} \mathrm{L}-1$
Additionally, in order to check the accuracy and precision of the sensor, the pharmaceutical vitamin $\mathrm{C}$ powder product "Cebion" was tested and the concentration was measured with $\mathrm{CuHCF}$ sensor. For a $50 \mu \mathrm{M}$ solution of AA, $50.15 \pm 0.12 \mu \mathrm{M}$ was found, and for $150 \mu \mathrm{M}$ AA, $149.03 \pm 0.24 \mu \mathrm{M}$ was found (six measurements in both cases), corresponding to recovery values of 100.3 and $99.4 \%$, respectively. These data show that the measurements performed with the $\mathrm{Cu}$ $\mathrm{HCF}$ sensor are precise and that this sensor can be used for determining ascorbic acid in juice and wines.

Table 3 shows the amount of ascorbate found in wines, ice tea and juice by standard addition of AA to diluted samples. The data obtained are in good agreement with the colorimetric enzyme test kit reference method. The lowest ascorbate concentrations were found in white wine and ice tea with lemon, and the ascorbate concentrations were much higher in red wines. According to the reflectometric analysis of AA, there is $0.4-1.5 \mathrm{mM}$ of AA in white and red wine [47]. In this case, the white wine analysed here had an AA concentration that was too low when compared to the reference; however, AA is usually added to wines that contain disulphide in order to convert it to a mercaptan $[1,48]$. A much higher concentration of ascorbate was present in the ice tea with lemon and in the commercial orange juice products, but these values fell within the range recommended in [49].

\section{Conclusions}

A new, improved sensor that can be used to electrocatalytically determine micromolar ascorbate concentrations at CuHCF-modified carbon film electrodes has been developed. This sensor functions at a low applied potential and has a low detection limit. Such sensors are constructed by depositing $\mathrm{CuHCF}$ films onto carbon film electrodes electrochemically (by potential cycling, galvanostatically, or chemically) and they were characterised by cyclic voltammetry and electrochemical impedance spectroscopy. CuHCF electrodes were successfully applied to the determination of ascorbate at neutral $\mathrm{pH}$ - for example in 0.1 M PBS, pH 7.0 - with good discrimination against potential interferents. The most suitable film was obtained by chemical deposition and was operated at $+0.05 \mathrm{~V}$ vsersus SCE. The linear range was $0.15-5 \mathrm{mM}$, with a limit of detection of $2.1 \mu \mathrm{M}$, and it was continuously usable for 20 days and stable for at least four months. The sensor was used to determine the ascorbate concentration in a pharmaceutical vitamin $\mathrm{C}$ product, and since the results demonstrated that the CuHCF sensor works accurately, and it was then successfully applied to the determination of ascorbate in wines and fruit juices.

Acknowledgements Financial support from Fundação para a $\mathrm{Ci}$ ência e Tecnologia (FCT) Portugal, ICEMS (Research Unit 103) and European Project HPRN-CT-2002-00186 are gratefully 
acknowledged. R. Pauliukaite and M.E. Ghica thank FCT for a postdoctoral fellowship (SFRH/BPD/14518/2003) and $\mathrm{PhD}$ grant (SFRH/BD/14014/2003), respectively. Prof. H.-D. Liess is thanked for the gift of the electrical resistors.

\section{References}

1. Francis FJ (ed)(1999) Wiley encyclopedia of food science and technology, 2nd ed, vol 4. Wiley, New York

2. Fornaro A, Coichev N (1998) Quim Nova 21:642-650

3. Martins LJA, da Costa JB (1988) J Chem Educ 65:176-178

4. Nübrega JA, Lopes JS (1996) Talanta 43:971-976

5. Koncki R, Wolfbeis OS (1998) Sens Actuat B 51:355-358

6. Koncki R, Lenarczuk T, G ąb S (1999) Anal Chim Acta 379:69-74

7. Li FB, Dong SJ (1987) Electrochim Acta 32:1511-1513

8. Totir N, Lupu S, Ungureanu NM, Giubelan M, Ştefanescu A (2001) Rev Roum Chim 46:1091-1096

9. Hart JP, Crew A, Crouch E, Honeychurch KC, Pemberton RM (2004) Anal Lett 37:789-830

10. de Mattos IL, Gorton L (2001) Quim Nova 24:200-205

11. Castro SSL, Balbo FR, Barbeira PJS, Stradiotto NR (2001) Talanta 55:249-254

12. Phournaghi-Azar MH, Razmi-Nerbin H (1998) J Electroanal Chem 456:83-90

13. Karyakin AA (2001) Electroanalysis 13:813-819

14. Shankaran DR, Narayanan SS (1999) Fresen J Anal Chem 364:686-689

15. Cai CX, Xue KH, Xu SM (2000) J Electroanal Chem 486:111118

16. Kulys J, D’Costa EJ (1991) Anal Chim Acta 243:173-178

17. Doherty AP, Stanley MA, Vos JG (1995) Analyst 120:23712376

18. Florou AB, Prodromidis MI, Tzuowara-Karayanni SM, Karayannis MI (2000) Anal Chim Acta 423:107-114

19. Roy PR, Saha MS, Okajima T, Ohsaka T (2004) Electroanalysis 16:289-297

20. Turkusic E, Milicevic V, Tahmiscija H, Vehabovic M, Basic S, Amidzic V (2000) Fresen J Anal Chem 368:466-470

21. Li J, Hu M, Yu R (1996) Sens Actuat B 30:65-69

22. Bradshaw MP, Prenzler PD, Scollary GR (2002) Electroanalysis $14: 546-550$

23. Malinauskas A, Garjonyte R, Mazeikienè R, Jureviciute I (2004) Talanta 64(1):121-129
24. Derwinska K, Miecznikowski K, Koncki R, Kulesza PJ, Glab S, Malic MA (2003) Electroanalysis 15:1843-1849

25. Yu J, Liu S, Ju H (2003) Biosens Bioelectron 19:401-409

26. Garjonyte R, Malinauskas A (2003) B Electrochem 19:529-534

27. Pan D, Chen J, Nie L, Tao W, Yao S (2004) Electrochim Acta 49:795-801

28. Mishima Y, Motonaka J, Maruyama K, Ikeda S (1998) Anal Chim Acta 358:291-296

29. Koncki R (2002) Crit Rev Anal Chem 32:79-96

30. Xu JJ, Fang HQ, Chen HY (1997) J Electroanal Chem 426:139-143

31. Garjonyte R, Malinauskas A (1999) Sens Actuat B 56:93-97

32. Shankaran DR, Narayanan SS (1999) Sens Actuat B 55:191194

33. Zhou JX, Wang EK (1994) Electroanalysis 6:29-35

34. Liu R, Sun B, Liu D, Sun A (1996) Talanta 43:1049-1054

35. de Mattos IL, Gorton L, Laurell T, Malinauskas A, Karyakin AA (2000) Talanta 52:791-799

36. Wang J, Zhang XJ, Prakash M (1999) Anal Chim Acta 395:1116

37. Wang J, Zhang XJ (1999) Anal Lett 32:1739-1749

38. Wang J, Zhang XJ, Chen L (2000) Electroanalysis 12:12771281

39. Brett CMA, Angnes L, Liess HD (2001) Electroanalysis 13:765-769

40. Filipe OMS, Brett CMA (2004) Electroanalysis 16:994-1001

41. Moscone D, D'Ottavi D, Campagnone D, Palleschi G, Amine A (2001) Anal Chem 73:2529-2535

42. García-Jareño JJ, Navarro JJ, Roig AF, Scholl H, Vicente F (1995) Electrochim Acta 40:1113-1119

43. Retter U, Widmann A, Siegler K, Kahlert H (2003) J Electroanal Chem 546:87-96

44. Cardwell TJ, Christophersen MJ (2000) Anal Chim Acta 416:105-110

45. Ijeri VS, Jaiswal PV, Srivastava AK (2001) Anal Chim Acta 439:291-297

46. Zhang L, Jia J, Zou X, Dong S (2004) Electroanalysis 16:14131418

47. Merck KGaA (2001) Ascorbic acid in red and white wine. Merck KGaA, Darmstadt, Germany (see http://pb.merck.de/ servlet/PB/show/1184870/asco15.pdf)

48. Eisenman L (1999) The home winemakers manual. Can be downloaded online at http://home.att.net/ lumeisenman.

49. Jongen W (ed)(2002) Fruit and vegetable processing - improving quality. Woodhead, Cambridge 